\begin{tabular}{lll}
\hline Jurnal Teknologi Kimia Unimal & $\begin{array}{l}\text { Jurnal } \\
\text { Teknologi } \\
\text { Kimia } \\
\text { Unimal }\end{array}$ \\
\hline
\end{tabular}

\title{
Pengaruh pH dan Waktu Ekstraksi Terhadap Karakteristik Pektin dari Kulit Coklat
}

\author{
Wusnah $^{1}$, Zulnazri ${ }^{2}$, Sulastri $^{3}$ \\ 1,2,3 Jurusan Teknik Kimia, Fakultas Teknik, Universitas Malikussaleh \\ Laboratorium Teknik Kimia, Jl. Batam No. 2, Bukit Indah, Lhokseumawe 24353 \\ e-mail:wusnah@yahoo.com
}

\begin{abstract}
Abstrak
Kulit buah coklat memiliki potensi yang besar untuk diolah menjadi sumber pektin dimana selama ini kulit buah coklat hanya merupakan limbah yang kurang bisa dimanfaatkan. Penelitian ini dilakukan untuk memanfaatkan kulit buah coklat sebagai sumber pektin dengan metode ekstraksi. Pada penelitian ini digunakan tiga variabel berubah yaitu pH ekstraksi 1,5; 2,6; 2,8; 3,0; waktu ekstraksi 60, 70, 80, 90 menit, dan perlakuan pencucian sampel dengan etanol dan aquadest. Dari hasil penelitian diperoleh hasil terbaik pada waktu ekstraksi 60 menit, pH 1,5 dengan perolehan kadar air 12,1\%, kadar metoksil 3,028 \%, dan kadar galakturonat 41,373\%, sedangkan rendemen terbanyak diperoleh pada waktu ekstraksi 90 menit, pH 2,8 yaitu 9,68 \%. Perlakuan pencucian sampel dengan etanol menghasilkan jumlah pektin yang tidak jauh berbeda dengan sampel dengan pencucian menggunakan aquadest, tetapi warna yang dihasilkan sedikit berbeda.
\end{abstract}

Kata kunci : Kulit Buah Coklat, Ekstraksi, Pektin

\section{Pendahuluan}

Pektin sangat diperlukan dalam pembuatan selai, jelly maupun dalam industri kembang gula. Pektin terdapat hampir di seluruh bagian tanaman terutama pada buah-buahan, seperti kulit jeruk, kulit coklat, pepaya, apel, wortel,kulit pisang, alpukat dan lain-lain (Nurjannah, 1998). Pektin dapat digunakan juga dalam industri-industri teknologi umum seperti pengental lateks karet dan zat yang mengundang pektin dapat dihidrolisis dengan alkali untuk menghasilkan zat pembentuk buih pada cairan pemadaman kebakaran (Agus dan Yulianingsih, 2011). 
Kulit buah coklat dapat diolah menjadi sumber pektin. Karena kulit buah coklat mengandung pektin $18 \%$, tanin $2 \%$, katekin $0,01 \%$ dan antocianin $1,04 \%$. Kandungan pektin yang cukup besar dalam kulit buah coklat berpotensi untuk dikembangkan mengingat nilai ekonomisnya yang cukup tinggi (Arief Racmawan, dkk, 2005).

Penelitian-penelitian tentang proses untuk memperoleh pektin telah banyak dilakukan dari berbagai bahan diantaranya dari kulit pisang, kulit pepaya, ampas jeruk siam, wortel, alpokat. Penelitian ini dilakukan untuk memanfaatkan limbah kulit buah coklat sebagai upaya memanfaatkan limbah kulit buah coklat yang terbuang begitu saja setelah proses panen dari biji coklat. Sehingga pemanfaatan kulit buah sebagai sumber pektin selain dapat mengurangi sampah berupa limbah kulit buah coklat juga dapat meningkatkan daya guna dari kulit buah coklat itu sendiri dengan dimanfaatkan sebagai sumber pektin.

Kondisi ekstraksi pektin berpengaruh terhadap karaktistik pektin dan sifat fisik pektin tergantung dari karakteristik kimia pektin. Suhu yang tinggi selama ekstraksi dapat meningkatkan rendemen pektin. Suhu yang tinggi akan membantu difusi pelarut ke dalam jaringan tanaman. Waktu ekstraksi yang terlalu lama akan menyebabkan terjadinya hidrolisis pektin menjadi asam galakturonat (Agus dan Yulianingsih, 2008). Penelitian ini bertujuan untuk mengetahi pengaruh $\mathrm{pH}$ dan waktu ekstraksi untuk mendapatkan pektin dari kulit buah coklat dengan cara ekstraksi menggunakan asam klorida sebagai pelarut.

Selama ini bagian buah coklat yang dianggap mempunyai nilai ekonomis adalah bijinya, sedangkan kulitnya kurang dimanfaatkan. Kulit coklat merupakan limbah pengolahan dari biji coklat. Kulit ini biasanya hanya dibuang sebagai sampah, padahal sebenarnya kulit buah coklat ini dapat dimanfaatkan sebagai bahan dasar pembuatan pektin, makanan ternak, dan produksi biogas sehingga memiliki nilai ekonomis yang tinggi.

Salah satu pemanfaatan kulit coklat ini adalah digunakan sebagai pektin. Pektin merupakan komponen tambahan penting dalam industri pangan, 
kosmetika, dan obat-obatan, karena kemampuannya dalam mengubah sifat fungsional produk pangan seperti kekentalan, emulsi, gel. Selain digunakan sebagai gelling agents, senyawa pektin juga berfungsi sebagai dehydrating agents, emulsyng agents, dan protective colloids sehingga penggunaan pektin makin meningkat baik sebagai bahan baku industri pangan maupum industri non pangan (Akhmalludin dan Kurniawan, 2011).

Pektin berasal dari bahasa yunani, pectos yang artinya membeku atau menggumpal. Vangueli pada tahun 1790 yang pertama sekali menemukan adanya zat yang dapat membentuk jel yang berasal dari buah-buahan dan berhasil mengisolasinya sebagai zat yang dapat larut dalam air. Pektin sebagai hasil industri mempunyai banyak manfaat, diantaranya bahan dasar industri makanan dan minuman, industri farmasi. Pektin sebagai asam poligalakturonat yang larut dalam air mengandung metil ester dengan derajat netralisasi yang bervariasi dan mempunyai sifat koloid serta dapat membentuk gel dengan gula dan asam pada kondisi tertentu.

Pektin terdapat hampir pada seluruh bagian tanaman dengan kadar tinggi pada buah-buahan. Pektin dapat diperoleh dari kulit buah coklat, kulit jeruk, kulit pisang, pepaya, apel, alpukat, nangka dan kentang. Secara lebih khusus, pektin dapat didefinisikan sebagai suatu senyawa kompleks yang merupakan turunan karbohidrat kolodial yang dapat diperoleh dari tanaman. Unsur penyusun pektin sebagian besar terdiri asam-asam anhidro galakturonat yang diperkirakan terdapat dalam suatu kombinasi yang berbentuk rantai. Sebagai gugus karboksil dari asam poligalakturonat dapat diesterifikasi oleh gugus metol dan sebagian atau seluruhnya dapat dinetralkan oleh basa (Heryani, 2001).

Pektin pada tanaman banyak terdapat pada lapisan kulit pada buah. Pektin dapat membentuk gel dengan bantuan adanya asam dan gula. Penggunaannya yang paling umum adalah sebagai bahan perekat pengental (gelling agent) pada selai dan jelly. Pemanfaatannya sekarang meluas sebagai bahan pengisi, komponen permen, serta sebagai stabiliser emulsi untuk jus buah dan minuman 
dari susu, juga sebagai sumber serat dalam makanan (Satria dan Ahda, 2011). Karakteristik pektin dapat dilihat dalam Tabel 1.

Tabel 1. Karakterisasi pektin

\begin{tabular}{|l|l|}
\hline Karakteristik & Nilai (maksimum) \\
\hline Kadar Air & 12 Persen \\
\hline Kadar Abu & 7 Persen \\
\hline Pektin Bermetoksil Tinggi (minimum) & 7 Persen \\
\hline Pektin Bermetoksil rendah & $2,5-7$ Persen \\
\hline Asam Galakturonat (minimum) & 35 Persen \\
\hline
\end{tabular}

(Sumber: Rachmawan dkk, 2005)

\section{Metode Penelitian}

\subsection{Bahan dan Alat}

Penelitian ini dilakukan di Laboratorium Jurusan Teknik Kimia Universitas Malikussaleh. Bahan yang digunakan untuk penelitian ini adalah kulit coklat (selaput bagian dalam) yang merupakan sisa pengambilan biji coklat serta bahan untuk anlisis kimia. Alat-alat yang digunakan adalah $\mathrm{pH}$ meter, stop watch, timbangan, hot plate, oven, dan alat-alat gelas.

\subsection{Metode}

Penelitian ini dilakukan dalam beberapa tahapan yaitu dimulai dengan tahap penghalusan bahan baku, tahap ekstraksi samapai tahap analisa. Secara rinci tahapan untuk mendapatkan pektin kering disajikan pada diagram alir Gambar 1. Karakterisasi pektin meliputi rendemen, kadar air, kadar metoksil dan kadar galakturonat. 


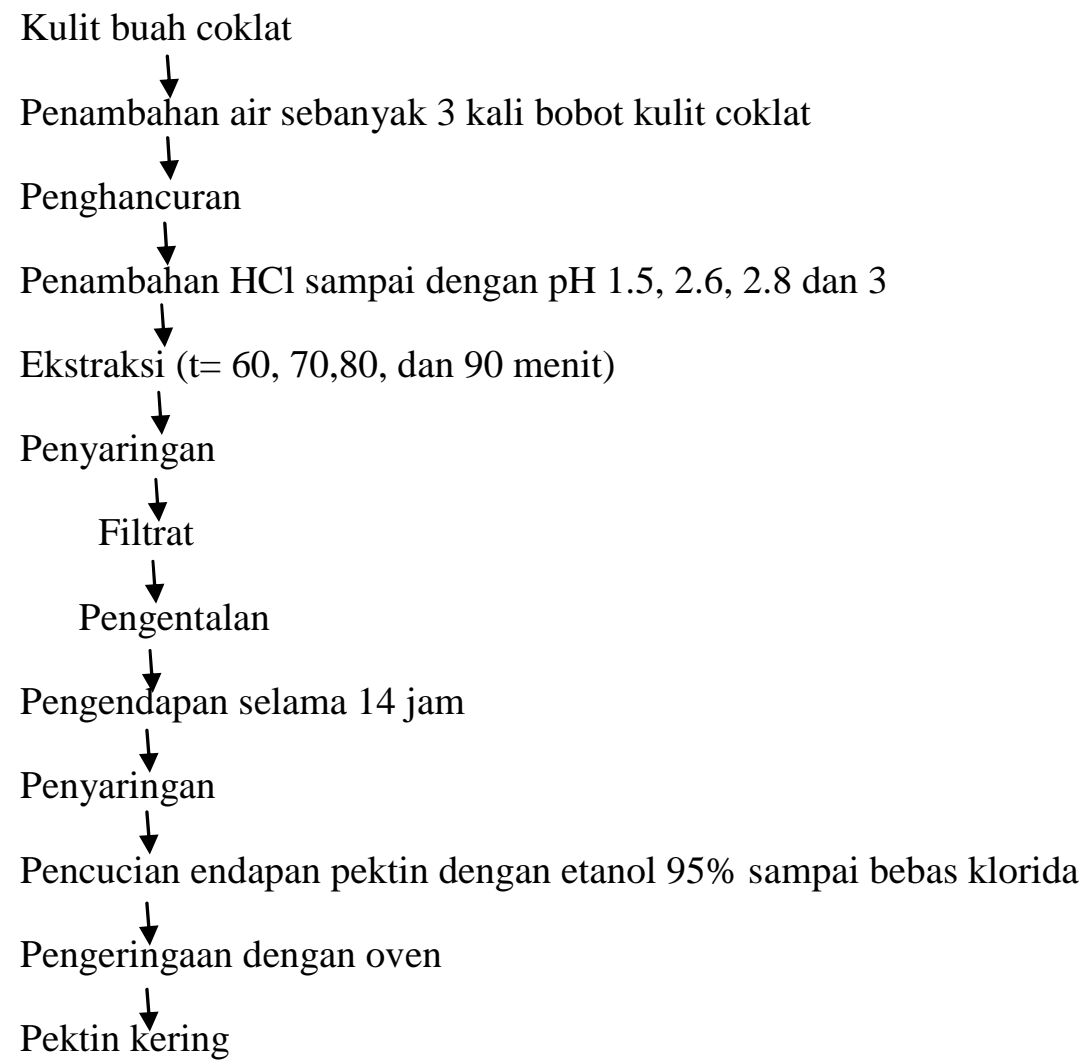

Gambar 1. Diagram alir ekstraksi pektin dari kulit buah coklat

\section{Hasil dan Diskusi}

Bahan yang digunakan dalam penelitian adalah kulit buah coklat segar tanpa pengeringan, pektin hasil penelitian kemudian dibandingkan dengan mutu pektin komersial. Spesifikasi mutu pektin komersial adalah : kadar air maksimum $12 \%$, kadar abu maksimum $1 \%$, pektin bermetoksil rendah maksimum 7\%, dan kadar galakturonat minimum $65 \%$.

Proses ekstraksi pektin dari kulit buah coklat dilakukan dengan menggunakan pelarut asam klorida $(\mathrm{HCl})$, dimana jumlah asam klorida yang ditambahkan divariasikan untuk mendapatkan kondisi $\mathrm{pH}$ yang ditetapkan sesuai variabel penelitian, selain dari itu waktu ekstraksi juga divariasikan sesuai dengan yang telah ditentukan serta pencucian dilakukan dengan menggunakan etanol dan aquades. 


\subsection{Pengaruh Waktu dan pH terhadap Berat Pektin}

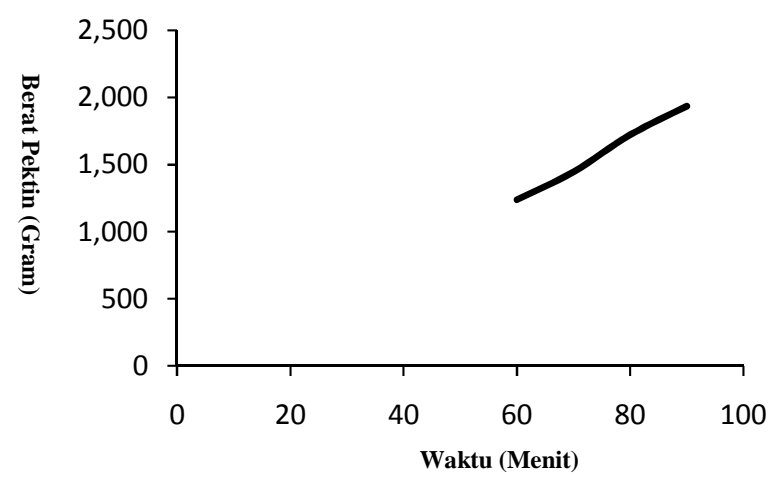

Gambar 2. Pengaruh waktu ekstraksi terhadap berat pektin

Banyaknya pektin yang dihasilkan sangat dipengaruhi oleh waktu ekstraksi, hal tersebut terlihat seperti yang ditunjukkan pada Gambar 2 dengan semakin lama waktu ekstraksi yang dilakukan pektin yang didapatkan juga semakin meningkat hal tersebut dikarenakan kontak antara pelarut dengan zat terlarut terjadi semakin lama sehingga pelarut mampu mengikat lebih banyak senyawa pektin, sehingga jumlah pektin tertinggi diperoleh pada waktu ekstraksi 90 menit, tetapi dari hasil penelitian ini belum diperoleh pada waktu ekstraksi berapa menit pelarut tidak mampu lagi mengekstrak pektin.

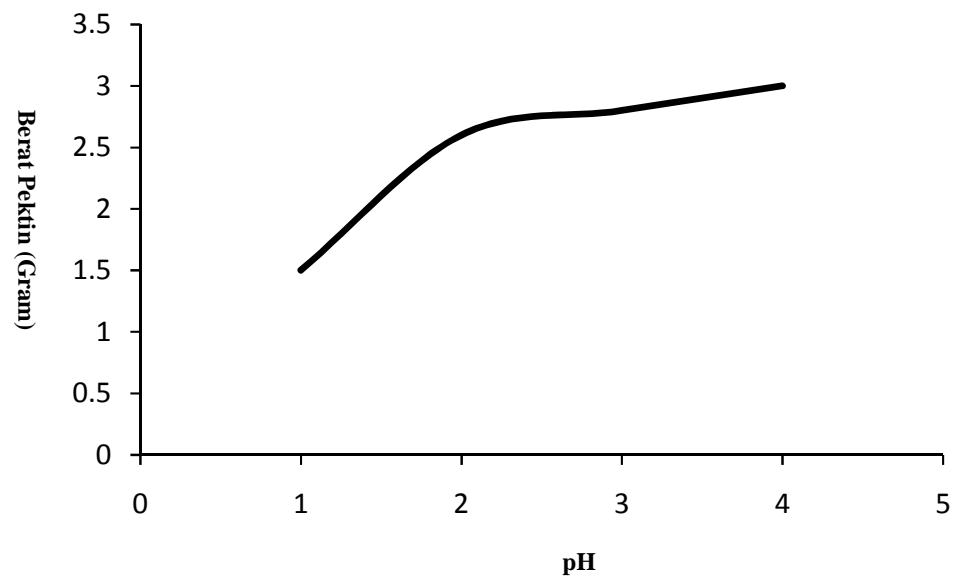

Gambar 3. Pengaruh $\mathrm{pH}$ terhadap berat pektin 
Dari Gambar 3 dapat diketahui bahwa $\mathrm{pH}$ sangat mempengaruhi proses ekstraksi pektin dari kulit coklat karena proses yang dilakukan menggunakan pelarut asam klorida, dari hasil penelitian didapatkan dengan meningkatnya $\mathrm{pH}$ semakin banyak pektin yang dihasilkan. Dari hasil penelitian diperoleh pada $\mathrm{pH} 3$ diperoleh berat pektin terbanyak.

\subsection{Karakteristik Pektin Hasil Ekstraksi}

Karakteristik pektin yang dikaji pada penelitian ini meliputi rendemen, kadar air, kadar metoksil dan kadar galakturonat. Dari Gambar 4 diperoleh bahwa waktu ekstraksi sangat mempengaruhi terhadap rendemen pektin yang didapat karena semakin lama waktu ekstraksi semakain banyak pektin yang terekstrak, akan tetapi karena kemampuan pelarut untuk mengekstraksi terbatas, maka bila telah melewati titik jenuhnya bila waktu ekstraksi diperpanjang tidak akan menambah hasil dari pektin itu sendiri.
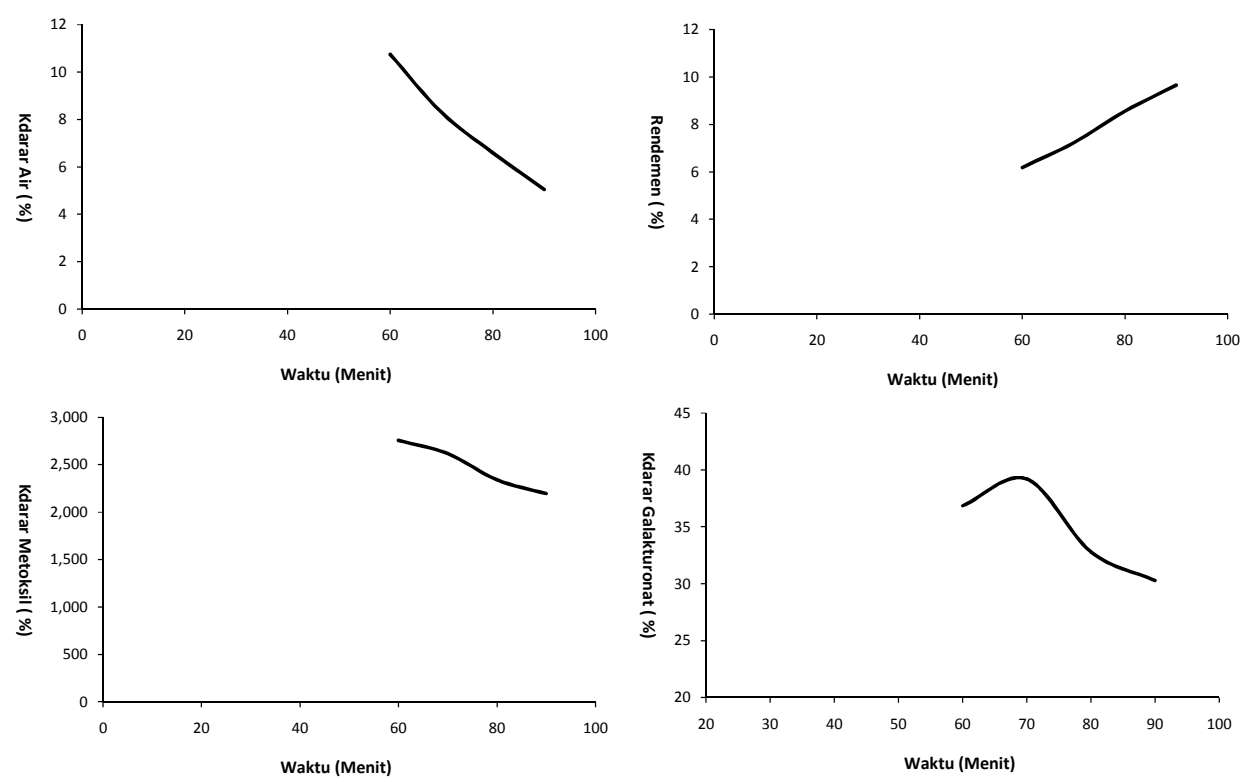

Gambar 4. Pengaruh Waktu Ekstraksi terhadap Kadar Air, Rendemen, Kadar Metoksil dan Kadar Galakturonat 
Gambar 4 memperlihatkan bahwa kadar air dan kadar metoksil berbanding terbalik dengan perolehan rendemen dimana semakin lama proses ekstraksi berlangsung kadar air dan kadar metoksil semakin turun demikian juga dengan kadar galakturonat walaupun awalnya mengalami peningkatan tetapi kemudian juga semakin menurun, hal tersebut terjadi karena bila waktu ekstraksi maksimum telah terlewati maka hasil pektin yang didapat akan mengalami penurunan dikarenakan pektin yang terbentuk mengalami hidrolisa lebih lanjut menjadi asam pektat. Gambar 4 juga menunjukkan bahwa kadar air dan kadar metoksil yang diperoleh sesuai dengan karakter pektin komersial. Pencucian sampel menggunakan aquadest maupun etanol tidak berpengaruh terhadap hasil pektin yang diperoleh hanya mempengaruhi perolehan warna pektin dengan pencucian menggunakan etanol menghasilkan warna putih kekuningan.

\section{Simpulan}

Semakin tinggi suhu dan waktu karbonisasi, maka kadar air semakin menurun. Kadar abu semakin meningkat dengan meningkatnya suhu dan waktu karbonisasi. Semakin rendah suhu dan waktu karbonisasi, maka rendemen pembentukan karbon aktif semakin meningkat atau sebaliknya. Karbon aktif dari kulit singkong mampu menjernihkan air sumur, sesuai dengan spesifikasi kualitas air bersih.

\section{Daftar Pustaka}

Ade Murni Suryani (2009), Pemanfaatan Tongkol Jagung Untuk Pembuatan Arang Aktif Sebagai Pemurnian Minyak Goreng Bekas, IPB, Bogor.

Anonymous (1979), Mutu dan Cara Uji Arang Aktif, Standar Industri Indonesia No. 0258-79, Departemen Perindustrian.

Djatmiko dan Prowiro (1970), Pembuatan Arang Aktif, Lembaga Ilmu Pengetahuan Indonesia, Bandung.

Hefni Effendi (2003), Telaah Kualitas Air, Edisi Cetak 7, Penerbit Kanisius, Yogyakarta.

Koran Jakarta, Karbon Aktif Kulit Singkong Sebagai Filter Air, Edisi Cetak 548, 19 Desember 2009. 
Lee, Richard (1989), Hidrologi Hutan, Gajah Mada University Press, (http://opac.geotek.lipi.go.id).

Peraturan Menteri Kesehatan RI No 82/2001, Syarat-syarat Pengawasan Kualitas Air, Jakarta.

Sari Wulan Intan Anisa (2005), Skripsi, Kualitas Air Bersih Untuk Pemenuhan Kebutuhan Rumah Tangga, UNS, Semarang.

Suherman, Ikawati, Melati (2009), Pembuatan Karbon Aktif Dari Limbah Kulit Singkong UKM Tapioka Kabupaten Pati, Seminar Nasional Teknik Kimia Indonesia, Bandung.

Sembiring, M., dan Sinaga, T (2003), Arang Aktif, Sumatera Utara, Jurusan Teknik Industri, Fakultas Teknik USU.

SNI 06-3730-95, Karbon Aktif

Sarwani (1989), Pengaruh Jenis Bahan Baku, Suhu, dan Waktu Aktivasi Terhadap Mutu dan Rendemen Karbon Aktif Hasil Aktivasi, Fakultas Teknologi Pertanian, IPB, Bogor.

Wenny Irawati, Ery Susiany (2008), Jurnal Penelitian, Pengaruh Temperatur dan Konsentrasi Zat Aktivator Pada Pembuatan Adsorben, Unika Widya Mandala Surabaya, Surabaya. 